\title{
Peran Transforming Growth Factor-ß1 pada Penyakit Ginjal
}

\author{
Partini Pudjiastuti Trihono \\ Departemen Ilmu Kesehatan Anak Fakultas Kedokteran Universitas Indonesia/RS Dr. Cipto Mangunkusumo, \\ Jakarta
}

\begin{abstract}
Peran sitokin dan faktor pertumbuhan (growth factor) sangat penting dalam proses inflamasi yang mendasari pembentukan jaringan sklerotik dan fibrosis pada glomerulonefritis. Transforming growth factor (TGF)- $\beta 1$ merupakan sitokin multipoten yang disekresi oleh berbagai sel dalam tubuh. Sitokin TGF- $\beta 1$ mempunyai kapasitas untuk mengaktivasi fibroblas interstisial, menginduksi apoptosis (yang menyebabkan sel intrinsik ginjal hilang, digantikan dengan jaringan fibrotik), dan diferensiasi sel tubulus menjadi miofibroblas, sehingga terjadi pembentukan jaringan parut ginjal. Jumlah (TGF)- $\beta 1$ di daerah tubulo-interstisial berkorelasi dengan derajat inflamasi interstisial dan atrofi tubulus. Keterlibatan TGF- $\beta 1$ pada pembentukan jaringan parut ginjal juga melalui peningkatan sintesis matriks ekstra selular. Diketahui bahwa TGF- $\beta 1$ berperan dalam progresivitas penyakit ginjal. Kadar TGF- $\beta 1$ di dalam urin kasus glomerulonefritis dengan proteinuria berat, sangat meningkat, dan kadarnya sebanding dengan derajat proteinuria. Peran TGF- $\beta 1$ dalam progresivitas penyakit ginjal juga melalui terjadinya hipertensi. Angiotensin II sebagai hasil aktivasi sistim renin-angiotensin menstimulasi produksi TGF- $\beta 1$. Inhibitor enzim konvertase (ACEI) dan atau antagonis reseptor angiotensin II terbukti dapat menurunkan proteinuria dan produksi TGF- $\beta 1$, sehingga kedua obat tersebut dikenal mempunyai efek reno-proteksi. Sari Pediatri 2011;13(1):49-54.
\end{abstract}

Kata kunci: Transforming growth factor (TGF)- $\beta 1$, glomerulonefritis, proteinuria

$\mathrm{P}$ enyakit ginjal kronik merupakan masalah kesehatan di seluruh dunia karena berjutajuta orang telah menjalani terapi pengganti ginjal, baik berupa dialisis maupun transplantasi. Kejadian tersebut merupakan beban fisik,

\footnotetext{
Alamat korespondensi:

DR. Dr. Partini Pudjiastuti Trihono, Sp.A(K). Divisi Nefrologi Anak. Departemen Ilmu Kesehatan Anak Fakultas Kedokteran Universitas Indonesia Jl. Salemba no. 6, Jakarta 10430. Telp. 021-3915179. Fax.0213907743.
}

psikologis, dan ekonomi, baik bagi pasien dan masyarakat. Penyakit ginjal kronik yang tersering ialah glomerulonefritis, nefropati diabetikum, nefritis interstisialis, dan vaskulitis. ${ }^{1}$ Sedangkan pada anak, manifestasi glomerulonefritis yang tersering adalah sindrom nefrotik idiopatik. Penyakit ginjal kronik sering disertai dengan proses inflamasi jaringan ginjal yang disebabkan oleh proses imunologis maupun non-imunologis. Pada awalnya terjadi inflamasi glomerulus diikuti dengan injury pada sel epitel tubulus dan rekruitmen sel-sel inflamasi. Selanjutnya terjadi pembentukan jaringan sklerotik dan fibrosis, 
akhirnya terjadi gagal ginjal terminal. Pada keadaan ini seseorang tidak dapat bertahan hidup lama lagi, kecuali mendapatkan terapi pengganti ginjal, berupa dialisis atau transplantasi. ${ }^{1}$ Dalam seluruh proses patofisiologis tersebut, peran sitokin dan faktor pertumbuhan (growth factor) sangat penting. Ekspresi sitokin yang diproduksi lokal di jaringan ginjal dapat menyebabkan berbagai reaksi, seperti produksi kemokin, akumulasi matriks ekstraselular, ekspresi adhesion molecules, dan produksi komponen komplemen ${ }^{1}$ (Gambar 1).

Sejak tahun 1974 telah diketahui bahwa sitokin mempunyai peran penting dalam penyakit ginjal. ${ }^{2}$ Penelitian menunjukkan bahwa sitokin di dalam glomerulus mempunyai peran dalam meningkatkan permeabilitas membran basalis, sehingga menyebabkan proteinuria. Selanjutnya berbagai penelitian invivo maupun invitro menunjukkan peran berbagai jenis sitokin, seperti interleukin (IL)-1, tumor necrosis factor (TNF)- $\alpha$, IL-6, platelet derived growth factor (PDGF), dan transforming growth factor (TGF)- $\beta$. Berbagai khemokin, seperti IL-8, monocyte chemoattractant protein (MCP)-1, dan RANTES (regulated upon activation normal T-cells expressed and secreted), juga berperan pada patogenesis berbagai penyakit ginjal. ${ }^{1}$ Tubulo-interstisial merupakan bagian ginjal yang sangat penting dalam menjalankan fungsi ginjal. Pada beberapa penyakit ginjal kronik, penurunan fungsi ginjal berhubungan dengan derajat fibrosis pada jaringan interstisial ginjal.

Infiltrasi sel inflamasi ke dalam jaringan interstisium tubulus menyebabkan penurunan laju filtrasi glomerulus pada pasien glomerulonefritis. ${ }^{3}$ Pada kelainan ginjal yang disebabkan oleh proses imunologik, ditandai dengan infiltrasi glomerulus dan jaringan tubulo-interstisial oleh neutrofil dan monosit/makrofag, ekspresi khemokin lokal akan mengakibatkan akumulasi leukosit ke tempat tersebut. ${ }^{4}$ Kejadian ini umumnya diawali dengan kerusakan jaringan yang disebabkan oleh reaksi antibodi terhadap antigen permukaan sel dengan atau tanpa disertai aktivasi sistem komplemen. Kerusakan jaringan IL-1 dan TNF- $\alpha$, yang selanjutnya menginduksi ekspresi berbagai khemokin. ${ }^{5}$

Penulisan makalah ini menjelaskan peran salah satu sitokin yaitu TGF- $\beta 1$ dalam penyakit ginjal.

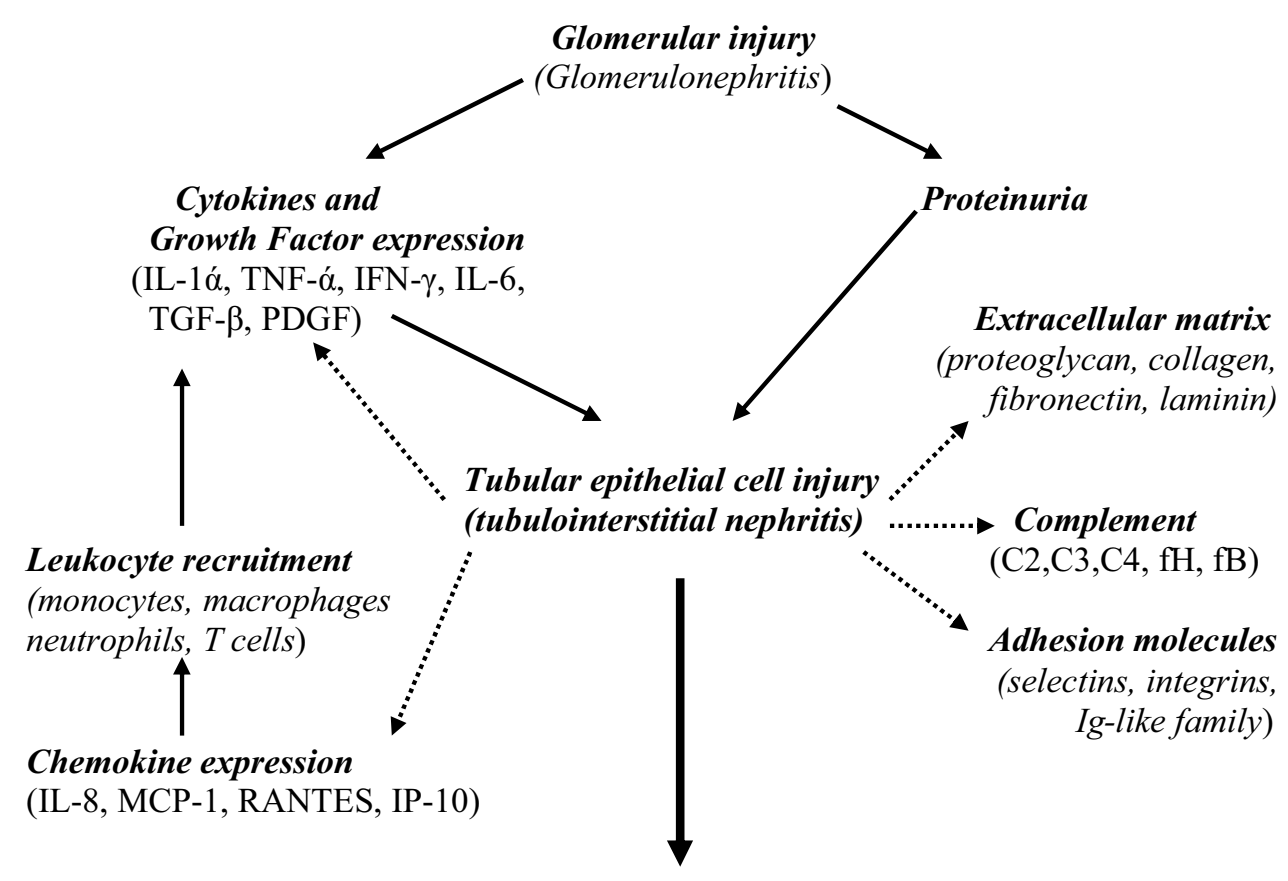

Chronic renal failure

Gambar 1. Berbagai proses yang terlibat dalam inflamasi ginjal ${ }^{1}$ 


\section{Transforming growth factor- $\beta 1$}

Transforming growth factor- $\beta$ (TGF- $\beta$ ) yang matur adalah protein dengan berat molekul $25 \mathrm{kD}$, secara aktif terlibat dalam proses perkembangan dan diferensiasi berbagai jenis sel. Sitokin TGF- $\beta$ disekresi oleh berbagai jenis sel, seperti sel trombosit, monosit/ makrofag, sel endotel, sel otot polos vaskular, dan sel mesangial. Terdapat tiga bentuk isoform TGF- $\beta$ pada mamalia, yaitu TGF- $\beta 1$, TGF- $\beta 2$, dan TGF- $\beta 3$. Telah diketahui bahwa TGF- $\beta 1$ merupakan isoform paling penting pada manusia, disekresikan dalam bentuk kompleks laten tidak aktif (prekursor), yang disebut kompleks latent TGF- $\beta$. ${ }^{6,78}$ Struktur kompleks latent $T G F-\beta$ terdiri dari fragmen terminal-C (merupakan bentuk aktif TGF- $\beta$ ) yang berikatan secara nonkovalen dengan fragmen terminal-N yang disebut $\beta 1$-LAP (latency associated peptide), membentuk molekul dengan berat molekul $100 \mathrm{kD}$. Proses pemecahan molekul besar ini diperlukan agar TGF- $\beta 1$ dapat berfungsi. Aktivasi TGF- $\beta 1$ melalui mekanisme enzimatik oleh glikosidase (endoglikosidase, sialidase, neuraminidase, $\mathrm{N}$-glikanase) dan enzim proteolitik yang menyebabkan degradasi LAP, seperti plasmin. ${ }^{7}$ Selain itu aktivasi TGF- $\beta 1$ dapat juga dilakukan dengan asidifikasi, alkalinisasi, pemanasan, pemberian deterjen, dan pemberian urea. ${ }^{67,8 .}$ Aktivasi latent $T G F-\beta$ dapat pula terjadi melalui interaksi langsung dengan thrombospondin-1 (TSP-1), yaitu protein perekat yang terletak di permukaan sel dan matriks ekstra selular, dan banyak ditemukan pada granula $\alpha$ trombosit. ${ }^{7}$ Setelah disekresikan ke dalam lingkungan ekstrasel, TGF- $\beta$ berinteraksi dengan berbagai protein pengikat dan reseptor membran spesifik. Setelah berikatan dengan kompleks reseptor, TGF- $\beta 1$ memberi signal transduksi ke nukleus, kemudian diikuti dengan regulasi transkripsi gen. ${ }^{6,7,8}$

Transforming growth factor $-\beta 1$ (TGF- $\beta 1$ ) adalah sitokin yang mempunyai multifungsi. Dari penelitian invitro maupun invivo disimpulkan bahwa TGF- $\beta$ mempunyai tiga aktivitas biologik terpenting, yaitu dampak biologik terhadap proliferasi sel, matriks ekstra selular, dan efek imunosupresif. ${ }^{6,7,9}$

Transforming growth factor- $\beta$ mempunyai dua dampak terhadap proliferasi sel, yaitu inhibisi dan stimulasi sehingga disebut sebagai cellular switch, apabila sesuatu di dalam sel dalam keadaan "off" TGF- $\beta$ akan mengubahnya menjadi "on", dan sebaliknya. ${ }^{9}$ Fungsi TGF- $\beta 1$ juga menghambat proliferasi keratinosit, tetapi menstimulasi proliferasi osteoblast dan sel Schwann. ${ }^{6,9}$ Pada fibroblas fetus manusia dari fetus dengan berat kurang dari 50 gram, TGF- $\beta 1$ beraksi sebagai stimulator, namun pada fetus dengan berat lebih dari $100 \mathrm{~g}$, TGF- $\beta 1$ bekerja sebagai
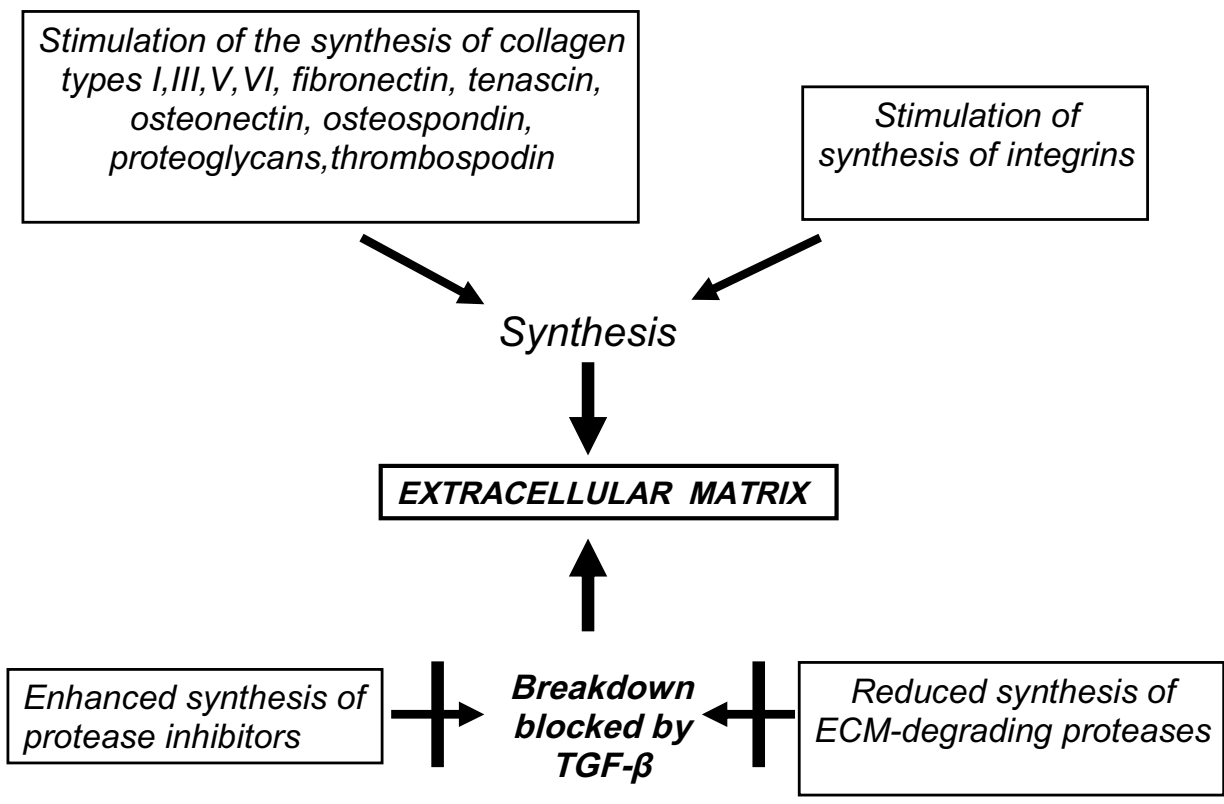

Gambar 2. Efek kumulatif TGF- $\beta$ pada pembentukan matriks ekstra selular ${ }^{6}$ 
inhibitor. ${ }^{6}$ Di samping dampaknya terhadap proliferasi sel, TGF- $\beta$ juga mempunyai peran ganda (inhibisi dan stimulasi) terhadap diferensiasi sel. Peran lain TGF- $\beta$ mempromosi diferensiasi epitel bronkus pada manusia, namun menghambat diferensiasi mioblas menjadi miotubul pada tikus, sedangkan pada sintesis hormon steroid TGF- $\beta$ TGF- $\beta$ mempunyai peran ganda (dikutip dari Lawrence D). ${ }^{6}$

Komponen matriks ekstra selular $(\mathrm{ECM}=$ extra cellular matrix); seperti kolagen tipe I,II, V, VI, fibronectin, tenascin, chondroitin, dermatan sulfat, hyaluronic acid, mempunyai peran yang penting dalam interaksi selular. Interaksi selular berguna mengendalikan migrasi sel dan morfologi jaringan, sehingga sangat berperan dalam embriogenesis, pemulihan jaringan (tissue repair), dan invasi tumor. Dilaporkan TGF- $\beta 1$ bekerja sebagai stimulator pembentukan ECM, melalui resultante dari 4 proses hasil kerja TGF- $\beta 1$, yaitu 1) stimulasi sintesis komponen ECM, 2) stimulasi sintesis integrin, yaitu reseptor membran yang memungkinkan sel mengenali molekul ECM tertentu pada membran basalis maupun sel lain, 3) menghambat sintesis protease inhibitor yang berfungsi memecah ECM, dan 4) mengurangi sintesis enzim ECM-degrading protease yang memecah ECM ${ }^{6.8}$ (Gambar 2). Disamping itu, TGF- $\beta$ juga menstimulasi produksi beberapa faktor pertumbuhan (growth factor) seperti basis fibroblast growth factor (bFGF) dan platelet derived growth factor (PDGF) yang juga menstimulasi pembentukan protein matriks ekstra selular.

Dampak imunosupresif TGF- $\beta 1$ berupa penghambatan proliferasi sel thymocytes, sel limfosit $T$ dan limfosit $\mathrm{B}$, sehingga berakibat penurunan produksi imunoglobulin. Sebaliknya, TGF- $\beta 1$ meningkatkan sekresi imunoglobulin A dari mukosa. Selain itu TGF- $\beta$ juga menghambat aktivitas sel natural killer (NK) dan menghambat produksi (namun tidak menghambat aktivitas) sel T sito-toksik. ${ }^{6}$ Sedangkan TGF- $\beta 1$ mempunyai daya tarik terhadap fibroblas (chemotactic attractant) dan monosit.

\section{Hubungan TGF- $\beta 1$ dengan penyakit ginjal}

Penelitian pada binatang menunjukkan bahwa pemberian antibodi anti-TGF- $\beta 1$ memperbaiki glomerulonefritis. ${ }^{6}$ Sintesis TGF- $\beta 1$ mRNA ditemukan terutama di epitel tubulus proksimal dan tubulus distal kasus glomerulonefritis dengan proteinuria berat, sedangkan protein TGF- $\beta 1$ ditemukan di dalam sitoplasma sel tubulus proksimal, tubulus distal, dan duktus koligentes. ${ }^{10}$ Jumlah TGF- $\beta 1$ di daerah tubulo-interstisial berkorelasi dengan derajat inflamasi interstisial dan atrofi tubulus. ${ }^{10,11}$ Kadar TGF- $\beta 1$ di dalam urin kasus glomerulonefritis dengan proteinuria lebih tinggi secara bermakna dibandingkan dengan kadarnya pada pasien nefropati IgA tanpa proteinuria maupun dibandingkan dengan orang sehat. Kadar TGF- $\beta 1$ di dalam urin menurun secara bermakna pada pasien sindrom nefrotik yang mengalami remisi, sebaliknya kadarnya tetap tinggi pada sindrom nefrotik persisten. ${ }^{10,12}$ Kadar TGF- $\beta 1$ di dalam urin mempunyai korelasi positif dengan derajat proteinuria. ${ }^{10,12}$ Di sisi lain, kadar TGF- $\beta 1$ di dalam plasma tidak menunjukkan perbedaan antara kasus glomerulonefritis dengan proteinuria, atau tanpa proteinuria, dengan orang sehat. ${ }^{10,13}$

Penelitian klinis menyokong penelitian invitro yang menunjukkan bahwa protein yang difiltrasi oleh glomerulus akan diserap (uptake) oleh sel tubulus melalui proses endositosis. Selanjutnya merangsang kaskade reaksi biologik yang berakibat pelepasan zat vasoaktif dan chemoattractant sehingga terjadi akumulasi monosit dan stimulasi fibroblas yang berakhir dengan inflamasi interstisial dan fibrosis. ${ }^{10}$ Ditemukan bahwa TGF- $\beta 1$ mempunyai kapasitas untuk mengaktivasi fibroblas interstisial, menginduksi apoptosis (yang menyebabkan sel intrinsik ginjal hilang, digantikan dengan jaringan fibrotik), dan diferensiasi sel tubulus menjadi miofibroblas, sehingga terjadi pembentukan jaringan parut ginjal. Keterlibatan TGF$\beta 1$ pada pembentukan jaringan parut ginjal juga melalui peningkatan sintesis matriks ekstra selular. Inhibitor enzim konvertase (ACEI) dan atau antagonis reseptor angiotensin II terbukti dapat menurunkan proteinuria dan produksi TGF- $\beta 1$, sehingga kedua obat tersebut dikenal mempunyai dampak reno-proteksi. ${ }^{14,15,16}$

Hipertensi dan penyakit parenkim ginjal saling berkaitan satu sama lain. Penyakit ginjal primer mengakibatkan retensi air dan natrium sehingga menyebabkan hipertensi, sebaliknya hipertensi akan mempercepat progresivitas penyakit ginjal menuju gagal ginjal terminal.

Angiotensin II sebagai hasil aktivasi sistim renin angiotensin dan thrombospondin (TSP1), keduanya menstimulasi produksi TGF- $\beta$ oleh sel epitel tubulus dan fibroblas. Selanjutnya TGF- $\beta 1$ akan menyebabkan proliferasi fibroblas dan sel epitel tubulus, meningkatkan protein matriks ekstra selular 
melalui beberapa mekanisme. Di samping itu TGF- $\beta 1$ juga menstimulasi produksi endothelin-1 (ET-1) oleh sel endotel arteriol. ${ }^{17,18}$ Endothelin-1 meningkatkan produksi mesangial dan protein matriks interstisial. Pembentukan ECM oleh TGF- $\beta 1$ dan ET-1 akan menyebabkan elemen selular hilang, injury tubulus, fibrosis, serta hilangnya struktur nefron. ${ }^{19}$ Penelitian pada binatang menunjukkan bahwa inhibitor enzim konvertase (ACEI = angiotensin converting enzyme inhibitor) dan antagonis reseptor angiotensin II pada tikus, mempunyai efek antifibrotik, berupa penurunan ekspresi TGF- $\beta 1$, penurunan akumulasi matriks, penurunan produksi fibronectin dan produksi inhibitor protease plaminogen-activator-inhibitor type 1 (PAI-1). ${ }^{20}$ Penelitian-penelitian in vivo pada manusia menunjukkan hasil yang sama. ${ }^{21,22}$

\section{Ringkasan}

1. Transforming growth factor (TGF)- $\beta 1$ merupakan sitokin multipoten yang disekresi oleh berbagai sel seperti sel trombosit, monosit/makrofag, sel endotel, sel otot polos vaskular, dan sel mesangial, dalam bentuk laten/inaktif.

2. Dampak biologis TGF- $\beta 1$ dapat dikelompokkan menjadi empat jenis.

a. Dampak terhadap proliferasi dan diferensiasi berbagai jenis sel. TGF- $\beta 1$ mempunyai efek ganda, yaitu stimulasi pada sel tertentu, dan inhibisi pada sel lain.

b. TGF- $\beta 1$ mempunyai peran penting dalam pembentukan protein matriks ekstra selular.

c. TGF- $\beta 1$ mempunyai efek imunosupresif dengan menghambat proliferasi sel limfosit $\mathrm{T}$ dan sel limfosit $\mathrm{B}$, menghambat aktivitas sel natural killer dan menghambat produksi set $\mathrm{T}$ sito-toksik

d. TGF- $\beta 1$ mempunyai efek chemoattractant terhadap fibroblas dan monosit.

3. TGF- $\beta 1$ berperan dalam progresivitas penyakit ginjal. Kadar TGF- $\beta 1$ di dalam urin pasien glomerulonefritis dengan proteinuria berat didapatkan sangat meningkat, dan kadar sebanding dengan derajat proteinuria.

4. Peran TGF- $\beta 1$ dalam progresivitas penyakit ginjal juga melalui hipertensi. Angiotensin II sebagai hasil aktivasi sistim renin-angiotensin menstimulasi produksi TGF- $\beta 1$. Dilaporkan
TGF- $\beta 1$ menstimulasi produksi ET-1 oleh sel endotel arteriol, keduanya meningkatkan produksi matriks ekstra selular sehingga menyebabkan hilangnya elemen selular, injury tubulus, fibrosis, dan hilangnya struktur nefron.

5. Inhibitor enzim konvertase (ACEI) dan antagonis reseptor angiotensin II terbukti menurunkan kadar TGF- $\beta 1$ urin pada pasien proteinuria (sebagai antiproteinutria) dan juga mempunyai efek antifibrotik.

\section{Daftar pustaka}

1. Gerritsma JSJ. Role of chemokines and complement in renal disease. Tesis. Leiden: Rijksuniversiteit; 1996

2. Shalhoub RJ. Pathogenesis of lipoid nephosis: a disorder of T-cell function. Lancet 1974;2:556-60.

3. Hooke DH, Gee DC, Atkins RC. Leukocytes analysis using monoclonal antibodies in human glomerulonephritis. Kidney Int 1987;31:964-72.

4. Cattel V. Macrophages in acute glomerular inflammation. Kidney Int 1994;45:945-52.

5. Baggiolini M. Novel aspects of inflammation: interleukin-8 and related chemotactic cytokines. Clin Investig 1993;71:812-4.

6. Lawrence AD. Transforming growth factor- $\beta$ : an overview. Kidney Int 1995;47(Suppl 49):S19-23

7. Gleizes PE, Munger JS, Nunes I, Harpel JG, Mazzier R, Noguera I, Rifkin DB. TGF- $\beta$ latency: biological significance and mechanisms of activation. Stem Cells 1997;15:190-7.

8. Bottinger EP, Letterio JJ, Roberts AB. Biology of TGF- $\beta$ in knockout and transgenic mouse models. Kidney Int 1997;51:1355-60.

9. Sporn MB. The importance of context in cytokine action. Kidney Int 1997;51:1352-4.

10. Goumenos DS, Tsakas S, El Nahas AM, Alexandri S, Oldroyd S, Kalliakmani P, dkk.Transforming growth factor- $\beta 1$ in the kidney and urine of patients with glomerular disease and proteinuria. Nephrol Dial Transplant 2002;17:2145-52

11. Murakami K, Takemura T, Hino S, Yoshioka K. Urinary transforming growth factor- $\beta$ in patients with glomerular diseases. Pediatr Nephrol 1997;11:334-6.

12. Wasilewska AM, Zoch-Zwierz WM. Transforming growth factor- $\beta 1$ in nephrotic syndrome treated with cyclosporine and ACE inhibitors. Pediatr Nephrol 2004;19:1349-53. 
13. Weng Z, Yu L, Wang L, Hao Z, Zhang Y. The relation ship between transforming growth factor $\beta$ gene expression and steroid therapy in children nephritic syndrome. Dipresentasikan di the 9th Asian Congress of Pediatric Nephrology, 28-30 Oktober 2005, Beijing, China.

14. Agarwal R, Siva S, Dunn SR, Sharma K. Add-on angiotensin II receptor blockade lowers urinary transforming growth factor- $\beta$ levels. Am J Kidney Dis 2002; 39:486-92.

15. Park HC, Xu ZG, Choi S, Goo YS, Kang SW, Choi KH, dkk. Effect of losartan and amlodipine on proteinuria and transforming growth factor- $\beta 1$ in patients with IgA nephropathy. Nephrol Dial Transplant 2003;18:1115-21.

16. Praga M, Gutierrez E, Gonzalez E, Morales E, Hernandez E. Treatment of IgA nephropathy with ACE inhibitors: a randomized and controlled trial. J Am Soc Nephrol 2003;14:1578-83.

17. Klahr S and Morrissey JJ. The role of vasoactive compounds, growth factors and cytokines in the progression of renal disease. Kidney Int 2000;57[Suppl75]:S7-14.
18. Inoki K, Haneda M, Ishida T, Mori H, Maeda S, Koya $\mathrm{D}$, dkk. Role of mitogen-activated protein kinases as downstream effectors of transforming growth factor-beta in mesangial cells. Kidney Int 2000;58[Suppl 77]:7680.

19. Eddy AA. Molecular basis of renal fibrosis. Pediatr Nephrol 2000;15(3-4):290-301

20. Peters $H$, Border WA, Noble NA. Targeting TGF- $\beta$ overexpression in renal disease: maximizing the antifibrotic action of angiotensin II blockade. Kidney Int 1998;54:1570-80.

21. Agarwal R. Add-on angiotensin receptor blockade with maximized ACE inhibition. Kidney Int 2001; 59:2282-9.

22. Campistol JM, Inigo P. Transforming growth factor- $\beta 1$ and angiotensin II blockade in renal transplant recipients. Diunduh dari http://www.compendium.com.ar/cin2000/ conferences/campistol/campistol.html tanggal 22 Desember 2005. 